\title{
WOLVES IN YellowSTONE, JACKSON HOLE, AND THE NORTH FORK OF THE SHOSHONE RIVER: SIMULATING UNGULATE CONSEQUENCES OF WOLF RECOVERY
}

\author{
MARK S. BOYCE $\downarrow$ JEAN-MICHEL GAILLARD \\ DEPARTMENT OF ZOOLOGY AND PHYSIOLOGY \\ UNIVERSITY OF WYOMING • LARAMIE
}

\section{$\checkmark \quad$ INTRODUCTION}

The gray wolf (Canis lupus) was extirpated from Yellowstone National Park by U.S. Government personnel during 1914-1926. Since then, occasional reports of wolves in Yellowstone National Park have been recorded (Weaver 1978), but no recent records exist of wolves breeding in the park. In recent years, public attitudes towards predators have changed such that predators are more commonly viewed as an integral component of natural ecosystems (see e.g., Mech 1970, Despain et al. 1986, Dunlap 1988). An increasing proportion of the American public desires that wolves be reestablished in Yellowstone National Park (McNaught 1987, Bath 1991).

In 1987, the U.S. Fish and Wildlife Service approved a Recovery Plan for the Northern Rocky Mountain wolf (U.S. Fish \& Wildlife Service 1987). Before proceeding with wolf recovery, however, Congress appropriated funds in 1988 and 1989 and directed that studies be conducted by the U.S. Fish and Wildlife Service and the National Park Service to determine the effects of wolf recovery on ungulate populations. Boyce (1990) developed a predator-prey model for ungulate populations in Yellowstone National Park as a part of this Congressional charge to determine the probable outcome of wolf recovery.

Our purpose is to expand upon the simulation model of Boyce (1990) to predict the probable consequences of wolf reintroduction in Yellowstone National Park to ungulate populations in Jackson Hole and along the North Fork of the Shoshone River. As in the previous model, this model allows the user to choose among several likely management scenarios. By manipulating alternatives, the user of the model can explore the consequences of management actions. In particular, it is essential to be able to anticipate if wolves will be culled if they leave the parks, if poaching can be controlled within the park, and if hunting for bison and elk will continue in the Yellowstone River valley north of Gardiner, Montana.

Any such model must incorporate the natural variability in the environment, because the vagaries of climate can have enormous effects on ecological processes. Therefore, the model is a stochastic one, i.e., it contains random variation in climatic variables. Such stochastic model structure is important because it helps to educate the user that it is impossible to predict precisely the consequences of wolf recovery.

It is not the purpose of this effort to offer recommendations for whether wolf recovery should take place, but rather to provide resource managers with an additional tool which will assist them in making that decision. 
We thank J. Varley, F. J. Singer, N. Bishop, M. Hedrick, M. Meagher, and B. Smith for assistance in the formulation of this model. D. Gulley assisted with programming, and several people commented on the model at various stages in its development including P. Abrams, N. Bishop, R. Cook, E. O. Garton, D. Huff, M. Meagher, L. D. Mech, E. H. Merrill, R. Page, J. Peek, F. J. Singer, R. J. Taylor, D. Vales, J. Weaver, and J. Yorgason. Special thanks to G. Roby, F. J. Singer, and M. Meagher for access to unpublished data used in this modeling effort, and to C. J. Walters for his critical review and suggested revision of the functional response. M. S. Boyce acknowledges the Centre for Theoretical Studies, Indian Institute of Science, Bangalore for use of an office and computer facilities. M. S. Boyce was an employee of the National Park Service during part of the time that this model was developed.

\section{$\checkmark$ METHODS}

The core model structure is based on that developed by Boyce (1990), using stochastic difference equations. As in the previous model called program "WOLF", this version called program "WOLF5" has been developed for interactive use, and includes expanded maps showing the projected distribution of wolves. As before, the model is used to project time series of wolf and ungulate populations for 100 years into the future.

The principal development in this model is that it incorporates 2 additional areas: the Jackson Hole area south of Yellowstone National Park, and the area along the North Fork of the Shoshone River east of the park. A new multi-species logistic functional response is used in the revised model which probably better represents the response of wolves to alternative prey. In addition, a number of improvements to program "WOLF" have been incorporated into program "WOLF5." See Boyce and Gaillard (1991) for detailed core model structure and program options.

\section{$\bullet \quad$ RESUltS}

\section{UNGULATE POPULATION DYNAMICS WITHOUT WOLVES}

Perhaps the most striking outcome of ungulate population projections under program "WOLF5", as in previous versions of the model, is the high variance in population size through time. Yet, this variation is strictly empirically based. Variation in winter severity causes substantial population fluctuations in all ungulates in the Greater Yellowstone Ecosystem, and such fluctuations are well documented (Meagher 1971, Houston 1982). For example, in 1989 we observed an estimated $7,000-8,000$ decrease in elk numbers due to density dependence, hunting, drought, fire, and slightly above average winter severity (Singer and Schullery 1989, Singer et al. 1989, Boyce and Merrill 1991).

Average population sizes for elk and wolves tend to be lower in the stochastic model simulations than for deterministic calculations using the same parameter values. This is due to reduced long-term population trajectories in stochastic simulations (Boyce 1977) as well as to the general concavity of population growth rate in these density-dependent models (see Boyce and Daley 1980).

In general, the responses of ungulate populations to wolf recovery would appear less pronounced in "WOLF5" than in the original model of Boyce (1990). We believe this to be a consequence of the explicit spatial structure of the model which dampens population fluctuations over the 3 subpopulations. For example, fluctuations in Yellowstone may not be in synch with those in Jackson Hole or the North Fork such that when the populations are totalled across areas we see less extreme fluctuations in total population size. Despite this effect, however, the revised functional response used in this model results in a larger decline for moose and mule deer within Yellowstone National Park than in previous versions of the model.

\section{EFFECTS OF WOLVES ON UNGULATE POPULATIONS}

Elk. The outcome of the simulations depends upon a large number of variables under the control of the program user. Nevertheless, under all possible management scenarios, except those resulting in the extinction of wolves, the existence of wolves in the area will result in fewer prey over the long-term average. For elk we expect to see a reduction in average population size over the next 100 years of $5-20 \%$ subsequent to wolf recovery. Elk population response to various program options is summarized in Tables 1-3. Effects will be greatest in 
Table 1. Response to program alternatives in program "WOLF5" for wolves and ungulates in the Greater Yellowstone Ecosystem. Responses to alternatives are to be compared with the 100 -year deterministic projection with wolves under the default alternatives as listed in Table 4. The first 6 lines present mean populations and standard deviations for each species under default conditions, and the subsequent lines contain the proportional response resulting from each alternative in the program.

\begin{tabular}{|c|c|c|c|c|c|c|c|}
\hline OPTION & ALTERNATIVE & $\mathrm{N}_{\text {elk }}$ & $\mathrm{N}_{\text {bison }}$ & $\mathrm{N}_{\text {moose }}$ & $\mathbf{N}_{\text {deer }}$ & $\mathbf{N}_{\text {wolf }}$ & Kill* \\
\hline \multicolumn{8}{|c|}{ Stochastic Model $(n=1000)$} \\
\hline \multicolumn{2}{|c|}{ Default--no wolves } & 36726 & 2688 & 5909 & 10315 & - & 4575 \\
\hline \multirow{2}{*}{\multicolumn{2}{|c|}{$\begin{array}{l}\text { Stan. deviation } \\
\text { Default--with wolves }\end{array}$}} & 4547 & 318 & 84 & 10315 & - & 978 \\
\hline & & 32954 & 2289 & 5565 & 8397 & 109 & 4400 \\
\hline \multicolumn{2}{|c|}{ Stan. deviation } & 4492 & 312 & 114 & 716 & 42 & 969 \\
\hline \multicolumn{8}{|c|}{ Deterministic Model } \\
\hline \multicolumn{2}{|c|}{ Default--no wolves } & 37614 & 2685 & 5909 & 10322 & - & 4642 \\
\hline \multicolumn{2}{|c|}{ Default--with wolves } & 33779 & 2214 & 5527 & 8278 & 123 & 4496 \\
\hline \multicolumn{8}{|l|}{ Winter } \\
\hline \multirow[t]{2}{*}{ Climate } & Severe & -0.030 & -0.032 & -0.001 & 0.024 & -0.13 & 0.000 \\
\hline & Mild & 0.030 & 0.035 & 0.001 & 0.021 & 0.122 & -0.003 \\
\hline \multicolumn{8}{|l|}{ Migratory } \\
\hline Behavior & Nonmigr & 0.017 & 0.037 & 0.010 & 0.035 & -0.154 & 0.004 \\
\hline Elk Hunting & No hunt & 0.029 & -0.021 & -0.007 & -0.028 & 0.144 & -0.136 \\
\hline \multicolumn{8}{|l|}{ Conflicts } \\
\hline Wolf Culls & None & -0.043 & -0.077 & -0.026 & -0.067 & 0.333 & -0.02 \\
\hline Poaching & $20 \%$ & 0.054 & 0.1 & 0.033 & 0.106 & -0.463 & 0.018 \\
\hline
\end{tabular}

*Hunter harvest of elk

Yellowstone National Park, and east along the North Fork.

There is no combination of choices where wolves have devastating consequences to elk populations in the Greater Yellowstone Ecosystem. The reason is that social factors limit wolf densities (Packard and Mech 1980, 1983) such that the wolf population cannot attain total numbers high enough to depopulate the elk herds. Likewise, under no management scenarios do we see the development of a predator "pit" where low prey densities are sustained by wolf predation (see Gasaway et al. 1983, Page 1989).
Again, we attribute this to the high prey density and territorial population limitation by wolves.

With wolves present, elk populations still undergo substantial population fluctuations, although we observed a decrease in the coeffient of variation in elk numbers of approximately $10 \%$ with wolves present. This observation given the functional response (see eq. 11, Boyce and Gaillard 1991) is consistent with results reported by Boyce (1990) which were also based upon a stabilizing logistic functional response. Substituting this functional response with Holling's disc equation (Type II) yields 
Table 2. Response to program alternatives in program "WOLF5" for Jackson Hole. The mean population size for comparison of alternative responses are from deterministic projections for 100 years with default alternatives as listed in Table 4. The first 6 lines present mean population size and standard deviations for each species under default conditions, and the subsequent lines include the proportional response resulting from each alternative in the program.

\begin{tabular}{|c|c|c|c|c|c|c|c|}
\hline OPTION & ALTERNATIVE & $\mathrm{N}_{\text {ellk }}$ & $\mathrm{N}_{\text {bison }}$ & $N_{m o 000}$ & $\mathbf{N}_{\text {deer }}$ & $\mathbf{N}_{\text {wolf }}$ & Kill* \\
\hline \multicolumn{8}{|c|}{ Stochastic Model $(\mathrm{n}=1000)$} \\
\hline \multicolumn{2}{|c|}{ Default--no wolves } & 15187 & 147 & 5000 & 1500 & - & 3329 \\
\hline \multicolumn{2}{|c|}{ Stan. deviation } & 1337 & 3 & 51 & 35 & - & 968 \\
\hline \multicolumn{2}{|c|}{ Default--with wolves } & 14523 & 135 & 4629 & 1431 & 16 & 3165 \\
\hline \multicolumn{2}{|c|}{ Stan. deviation } & 1390 & 10 & 54 & 26 & 4 & 949 \\
\hline \multicolumn{8}{|c|}{ Deterministic Model } \\
\hline \multicolumn{2}{|c|}{ Default--no wolves } & 15373 & 147 & 5002 & 1501 & - & 3392 \\
\hline \multicolumn{2}{|c|}{ Default--with wolves } & 14529 & 136 & 4924 & 1426 & 17 & 3246 \\
\hline \multicolumn{8}{|l|}{ Winter } \\
\hline \multirow[t]{2}{*}{ Climate } & Severe & 0.001 & -0.029 & 0.002 & 0.003 & 0 & 0.001 \\
\hline & Mild & -0.005 & 0.022 & -0.004 & -0.006 & 0.118 & -0.004 \\
\hline \multicolumn{8}{|l|}{ Migratory } \\
\hline \multicolumn{8}{|l|}{ Gardiner } \\
\hline Elk Hunting & No hunt & -0.005 & -0.007 & -0.001 & -0.004 & 0.118 & -0.004 \\
\hline $\begin{array}{l}\text { Conflicts } \\
\text { w/humans }\end{array}$ & Frequent & 0.023 & 0.007 & 0.006 & 0.02 & -0.353 & 0.018 \\
\hline Wolf Culls & None & -0.036 & -0.007 & -0.009 & -0.029 & 0.529 & -0.028 \\
\hline Poaching & $20 \%$ & 0.033 & 0.007 & 0.009 & 0.029 & -0.529 & 0.026 \\
\hline
\end{tabular}

*Hunter harvest of elk

increased variation occurring in prey populations under predation. Effects of wolves on hunted populations of elk differ between areas. The Gardiner, Montana, hunt is a limited quota hunt, and only a relatively small fraction of the northern herd is harvested in any particular year. Given continued quota permit regulations, we expect no consequences of wolf recovery to the harvest of elk in Montana; rather we expect to see a reduction in herd size. In Jackson Hole and the North Fork, however, populations are harvested at higher rates, closer to the maximum sustained yield possible from these herds. Model predictions are that we can expect wolves to reduce the population size as well as reduce the average annual harvest of elk. However, the harvest reductions are relatively small: at least $5-10 \%$ for the Jackson elk herd and 1-2\% for the North Fork.

Bison. Overall, wolves are not expected to be nearly so effective at preying on bison as on elk and deer. Yet, in areas where wolf numbers are maintained high by alternative prey, particularly elk and deer, wolves can have a noticeable effect on bison populations. Given the default management scenario, the average bison population will be less 
Table 3. Response to program alternatives in program "WOLF5" for the North Fork of the Shoshone River area. The projected population size for comparison of alternative responses are from deterministic runs for 100 years using default alternatives as listed in Table 4. The first 6 lines present the mean populations and standard deviations for each species under default conditions, and subsequent lines contain the proportional response resulting from each alternative in the program.

\begin{tabular}{|c|c|c|c|c|c|c|}
\hline OPTION & ALTERNATIVE & $\mathbf{N}_{\text {elk }}$ & $\mathrm{N}_{\text {moose }}$ & $\mathbf{N}_{\text {deer }}$ & $\mathbf{N}_{\text {wolf }}$ & Kill* \\
\hline \multicolumn{7}{|c|}{ Stochastic Model $(n=1,000)$} \\
\hline \multicolumn{2}{|c|}{ Default--no wolves } & 5343 & 89 & 5512 & - & 637 \\
\hline \multicolumn{2}{|c|}{ Stan. deviation } & 896 & 2 & 162 & - & 154 \\
\hline \multicolumn{2}{|c|}{ Default--with wolves } & 5181 & 88 & 5341 & 7 & 633 \\
\hline \multicolumn{2}{|c|}{ Stan. deviation } & 967 & 2 & 157 & 2 & 162 \\
\hline \multicolumn{7}{|c|}{ Deterministic Model } \\
\hline \multicolumn{2}{|c|}{ Default--no wolves } & 5745 & 89 & 5518 & - & 650 \\
\hline \multicolumn{2}{|c|}{ Default--with wolves } & 5623 & 88 & 5315 & 8 & 650 \\
\hline \multicolumn{7}{|l|}{ Winter } \\
\hline \multirow{2}{*}{ Climate } & Severe & -0.027 & 0 & 0.009 & -0.125 & 0 \\
\hline & Mild & 0.028 & -0.011 & -0.003 & 0 & 0 \\
\hline \multicolumn{7}{|l|}{ Migratory } \\
\hline \multicolumn{7}{|l|}{ Gardiner } \\
\hline Elk Hunting & No hunt & 0 & 0 & 0 & 0 & 0 \\
\hline $\begin{array}{l}\text { Conflicts } \\
\text { w/humans }\end{array}$ & Frequent & 0.010 & 0 & 0.018 & -0.5 & 0 \\
\hline Wolf Culls & None & -0.009 & -0.011 & -0.016 & 0.5 & 0 \\
\hline Poaching & $20 \%$ & 0.012 & 0 & 0.02 & -0.5 & 0 \\
\hline
\end{tabular}

than $15 \%$ lower with wolves than without wolves. Bison population response to each of the program options is summarized in Tables 1-2.

Moose. The empirical data base for moose in the GYE is much less complete than for bison or elk, and consequently we cannot be as confident about the consequences of wolf recovery on moose. However, since moose are relatively low in number, they are not likely to have major ramifications to the overall behavior of the system. None of the management alternatives offered in program "WOLF5" create more than a $7 \%$ change in the abundance of moose (see Table 1), but heavier local effects may occur in the face of heavy hunting pressure on moose in
Montana. During winter, a substantial fraction of the Yellowstone moose population migrates out of the park, with many going to Jackson Hole. These animals are projected to bear little consequence from wolf recovery, whereas the moose that winter in the park will suffer much higher wolf predation.

Simulation results predict that wolf recovery will cause an average reduction in moose numbers by approximately $5 \%$, although this may be overly conservative. Again, a major concern is that portions of the park's moose population appear to be heavily hunted when they leave the park (Singer 1991). Consequently, the effects of wolf recovery may be greater on moose than other potential prey if current 
Table 4. Default responses to options in program "WOLF5."

OPTION

DEFAULT ALTERNATIVE

CLIMATE

MIGRATORY BEHAVIOR

ELK HUNT

CONFLICTS W/HUMANS

LEGAL WOLF CULLS

POACHING IN PARK

INOCULUM SIZE
AVERAGE CLIMATE

PARTIAL MIGRATIONS

CONTINUE ELK HUNT

WOLVES AVOID HUMANS

WOLVES CULLED OUTSIDE PARK

LITTLE POACHING MORTALITY

30 WOLVES RELEASED hunting kill rates are sustained.

The largest wintering concentration of moose in the Yellowstone area is in northern Jackson Hole. Densities of moose alone may be sufficient in this area to sustain a couple of wolf packs. This possibility is further enhanced by the occurrence of several hundred elk in the Buffalo Fork valley. Although prey in this area may be sufficient to support wolves, it is difficult to foresee how wolves will be managed in this area where private landowners may be affected.

Mule Deer. Although wolves preferred mule deer slightly more than elk, the total number of deer killed by wolves is expected to be far fewer than elk because of their lower population size. The effect of wolf predation on mean population size of mule deer is intermediate between that of elk and bison. Simulations suggest a reduction by $3-19 \%$ in mule deer numbers. Response of deer numbers to management alternatives are presented in Tables 1-3.

When building the model, we were concerned that there may be a risk that deer could be locally extirpated by wolves, especially on Yellowstone's Northern Range. Yet, we thought that this was unlikely because there should always be some deer near the town of Gardiner, Montana where a number of deer winter now. This motivated us to construct a refugium in program "WOLF5" to ensure that wolves did not reduce deer numbers below 700. As it turned out, however, wolf predation on deer only rarely drives deer numbers to the refugium level.

\section{WOLF POPULATION DYNAMICS}

Under most management scenarios, we expect to find between 50 and 170 wolves in the Yellowstone-Jackson-North Fork area during the century following reintroduction. Three of the options offered the user of program "WOLF5" involve an increase in the mortality rate for wolves, i.e., frequent conflicts with man, culling outside the park, and poaching within the park. Future wolf populations are highly sensitive to these options (see Table 1). If the user chooses to increase mortality in all 3 options, the survival rate for wolves would be 0.578 of that occurring without the human-induced mortality and the wolf population will often decline and may go extinct. This is in line with observations of Keith (1983) and Ballard et al. (1987) suggesting that wolf kills by man in excess of $40 \%$ caused a decline in wolf populations.

Users of program "WOLF5" will note that it is common to observe low frequency oscillations in the number of wolves, as illustrated in Figure 1 in 


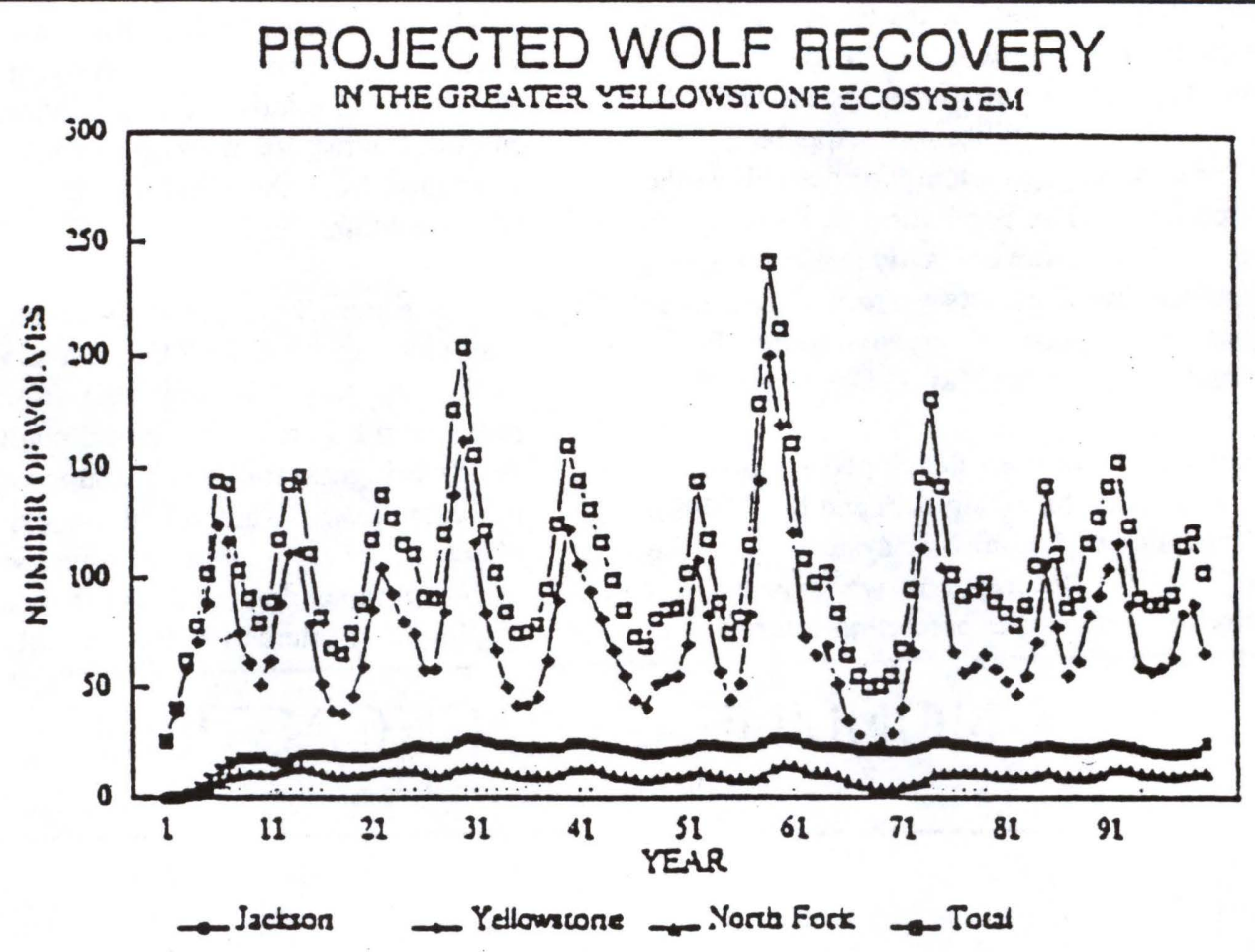

Figure 1. A projected population trajectory for wolves in Yellowstone National Park showing typical quasi-periodicity.

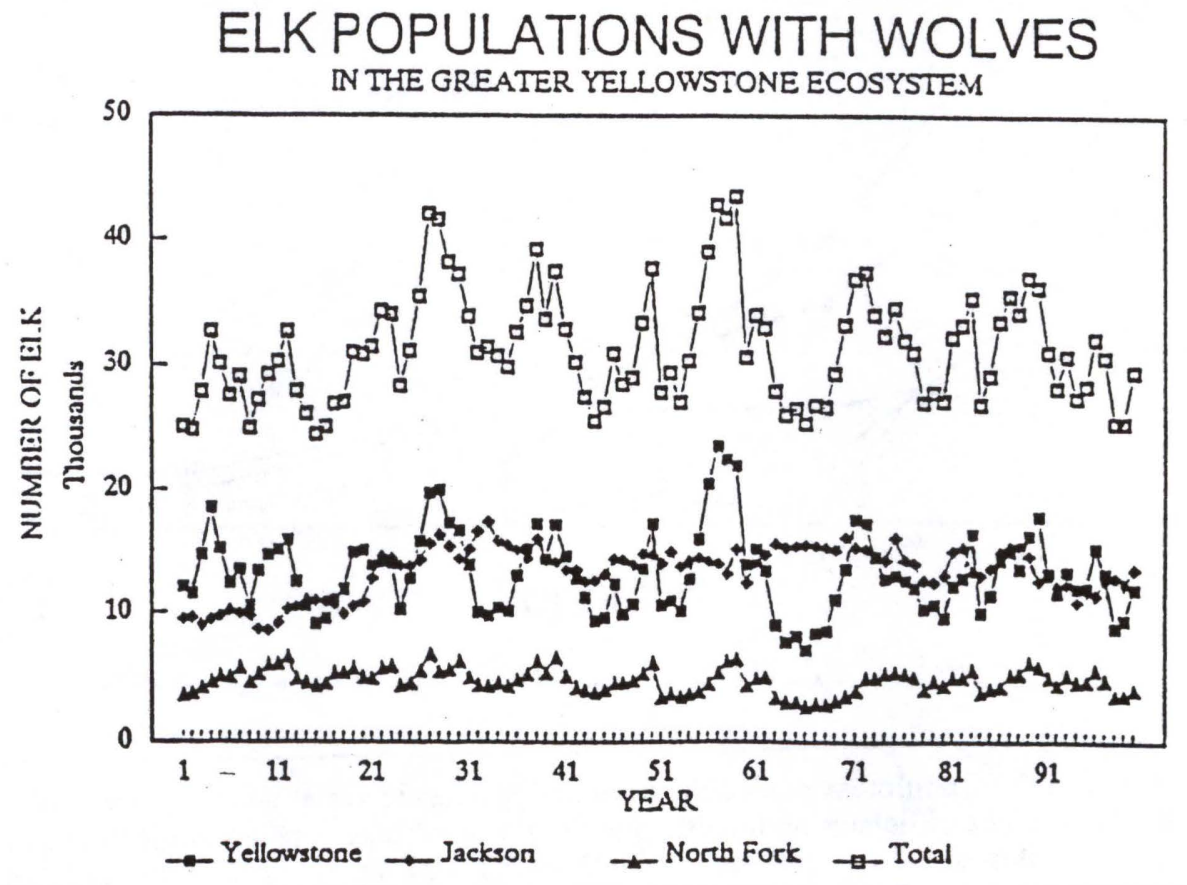

Figure 2. A population trajectory for elk under wolf predation in Yellowstone National Park generated by program WOLF5. 
contrast to the projection for elk shown in Figure 2. This is suggestive of nonlinear dynamics typical ofsome predator-prey systems. In deterministic simulations, no such oscillations appear and the system converges on equilibrium. Apparently the stochastic variation is great enough to destabilize the system temporarily. The population then undergoes transient motion back toward a dynamic attractor. Such destabilizing effects from stochastic perturbations have been observed previously in spatially structured models (May 1989).

A new method has been developed for analysis of such nonlinear structure (Sugihara and May 1990). Complex dynamics of a nonlinear system should be predictable into the future, but we expect such predictability to erode as the prediction interval increases. In contrast, purely stochastic processes might be expected to show the same level of predictability irrespective of the projection interval. Thereby, the relative role of random "noise" versus nonlinear structure in a population's dynamics can be discerned from the reliability of nonlinear forecasts into the future.

In Figure 3 we present such an analysis for the 5 species which we modelled in Yellowstone National Park. As might be expected from the dynamical patterns in Figures 1 and 2, the nonlinear forecasting ability is highest for wolves and lower for each of the other species. This might be expected since the effects of severe winters are direct and immediate on ungulate populations whereas they are buffered by a trophic-level interaction for the wolves.

\section{NONLINEAR FORECASTING \\ Yellowstone National Park}

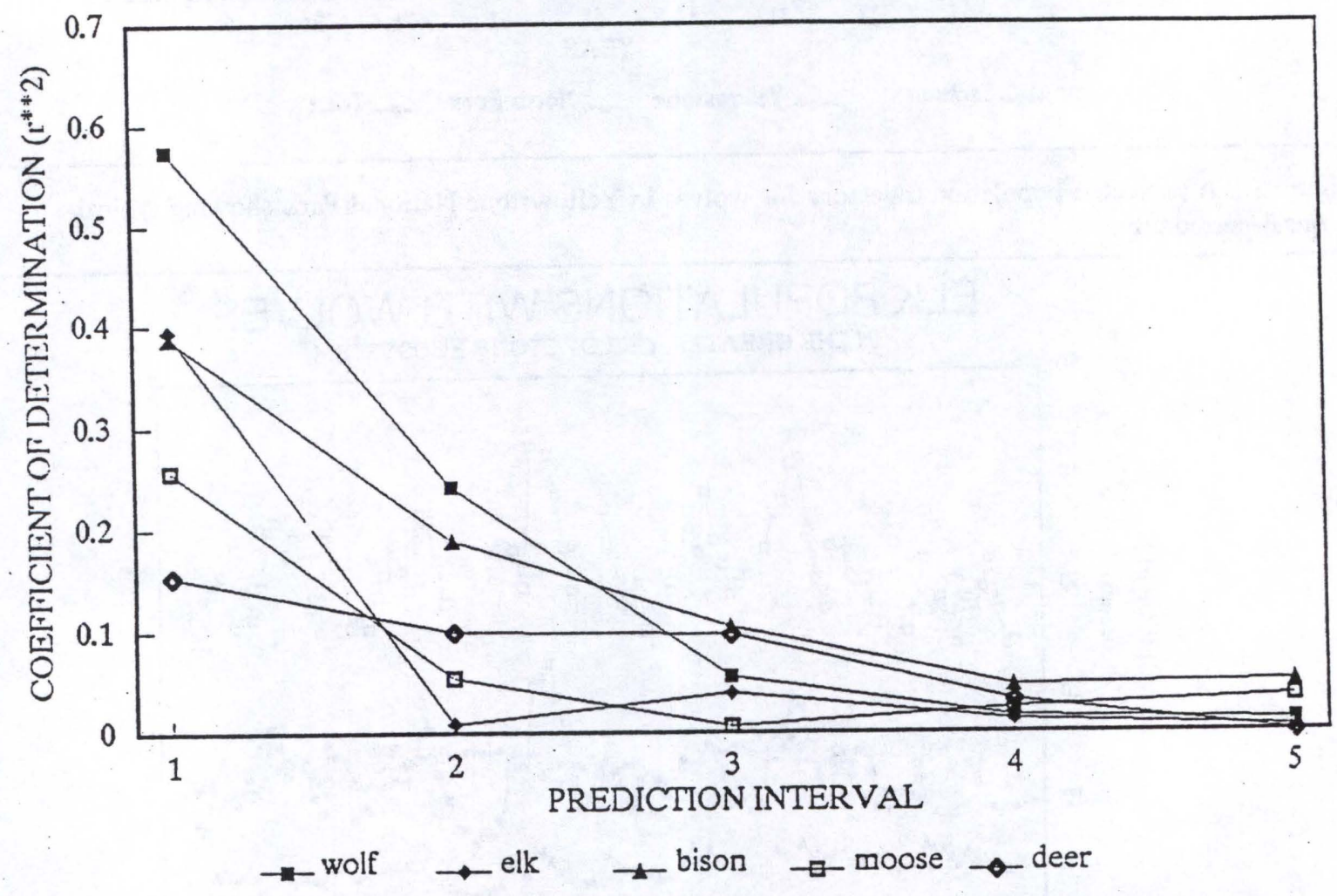

Figure 3. Combined role of nonlinear model structure and stochastic variation in program WOLF5 is shown by the decay in the coefficient of determination as a function of nonlinear forecast projection interval for 5 large mammal species in Yellowstone National Park. Nonlinear dynamics play a major role in the modelled dynamics of wolves whereas stochastic effects, i.e., severe winters, are more important to the population dynamics of the ungulate species. 


\section{- DISCUSSION}

Our view of population regulation for ungulates in the Greater Yellowstone Ecosystem does not differ substantially from the nonlinear plant-herbivore model described by Caughley and Lawton (1981). Since we had inadequate information to develop a complete plant-herbivore model, a trophic level is missing in program "WOLF5." Because there are several species incorporated into the model, it is nevertheless complex. Complex models, especially when driven by seasonal forcing (Inoue and Kamifukumoto 1984) can yield complex dynamics. However, our analysis of elk and bison population dynamics for the Northern Range herds showed no evidence of such complex dynamics, and indeed both species showed stable dynamics (Merrill et al. 1988). For the most part, population fluctuations can be attributed to stochastic variation in winter severity and summer range phytomass (Merrill and Boyce 1991), but not due to inherent instability in the dynamics for either elk or bison. However, the analysis of the model at Figures 1-3 suggest that excursions into regions of complex system behavior may occur under wolf predation with the addition of environmental stochasticity.

The features of wolf population regulation in program "WOLF5" are similar to those characterized by Packard and Mech $(1980,1983)$. Specifically, population regulation in wolves results from an interaction of social and nutritional variables. Pack territoriality sets an upper limit to wolf population size which is only attained when prey abundance is exceptionally high.

\section{CONSEQUENCES OF MANAGEMENT ALTERNATIVES}

Potential Conflicts With Hunting. One of the major concerns about wolf recovery is the possibility that predation on ungulates will substantially reduce populations of hunted game species, especially elk, moose, deer, and bighorn sheep (Zumbo 1987). Simulation results by Boyce (1990) indicate that there will indeed be a reduction in the number of these large mammals, although it does not appear that wolf predation should require that hunting opportunities be reduced. However, these results cannot be generalized to the Jackson elk herd or the North Fork of the Shoshone. In Jackson Hole and along the North Fork, ungulate management is much more harvest oriented with average yields approaching maximum sustained yield (Boyce 1989). Simulation results project a $5-10 \%$ reduction in harvest from the Jackson elk herd but only a 1-2\% reduction along the North Fork. These declines in elk harvest will be accompanied by a 4-8\% reduction in herd size in Jackson Hole and a 2-3\% reduction along the North Fork. Nevertheless, wolf predation is certainly compatible with a hunter-harvest program in areas adjacent to the national parks. In the same fashion that density dependence and compensatory mortality ensures sustained yield hunting opportunity, moderate predation by wolves will stimulate similar responses.

Under the default alternatives, program "WOLF5" projects that terminating the late Gardiner hunt in Montana will only increase the wintering population of elk in Yellowstone by $7 \%$, and in the total Yellowstone-Jackson Hole-North Fork area by $3-4 \%$. Interestingly, the increase in the elk population in Yellowstone is accompanied by a nearly $30 \%$ reduction in the coefficient of variation in mean elk numbers. This occurs because of the way that we modelled the elk hunt. For program "WOLF5," we presumed that the Montana Department of Fish, Wildlife and Parks will continue to annually issue 700 elk permits for the late Gardiner hunt. This would only change if the population of elk fell below 5,000 animals, whereupon the elk hunt would be temporarily discontinued. In reality, it seems probable that if elk numbers again become exceptionally high, as they were in 1988, the number of permits may be increased again. This would result in a density-dependent effect which would tend to stabilize elk numbers.

There are examples where conflicts between hunting and wolf predation have been sufficient to merit reductions in hunting opportunities (Mech and Karns 1977, Bergerud et al. 1983, Gasaway et al. 1983, Keith 1983, Gunson 1986). The reason that we expect this may not be necessary in the Yellowstone area is largely because hunting does not take place within the boundaries of Yellowstone National Park. Wolf predation rates on ungulates tend to be highest during late winter when the prey are most vulnerable (Carbyn 1974, 1983), and therefore the consequences of predation on transient summer herds will not be as great. In addition, during summer ungulate populations in the park more than double in size such that the predation is distributed over many more animals. 
"WOLF5" projects that total moose populations in the GYE will decrease by only $4-8 \%$, whereas, those wintering in Yellowstone National Park may decrease by more than $37 \%$ as a consequence of wolf recovery. This occurs because the large elk population increase wolf numbers, thereby increasing the encounter rate between wolves and moose. This could be resolved by reducing the hunting pressure on moose which winter on Yellowstone's Northern Range. I simulated such a closure, and found that wolves would only reduce moose numbers by $15 \%$ in Yellowstone if moose hunting were stopped in Montana.

An alternative perspective on the consequences of human harvest of ungulates on ungulate-wolf interactions is that potential wolf numbers may be reduced (see Table 1). Carbyn et al. (1987) postulated that wolf numbers in Riding Mountain National Park were not as high as they could be because of human harvests outside the boundaries of the park. According to program "WOLF5," terminating the late Gardiner hunt would allow an increase in the wolf population in Yellowstone National Park by $10-15 \%$, but eliminating the Gardiner elk hunt is not proposed or anticipated in reality.

Wolf recovery in the GYE may resolve a long-standing management issue in Grand Teton National Park, namely the elk herd reduction program within the park (Wood 1984). Since the inception of the program in 1950, the National Park Service has been uncomfortable with hunting in the park (Murie 1951). But because of the winter-feeding program at the adjacent National Elk Refuge, the hunt appears to be necessary to check population size and to ensure reasonable distribution of elk in the valley (Boyce 1989). Wolf predation should alleviate this. Wolves will surely be protected within Grand Teton National Park, thereby affording them refuge. And during summer Grand Teton supports a high proportion of the Jackson elk (Boyce 1989) herd, offering an ample prey base. By concentrating in areas of highest prey density (Fuller 1989), wolves may help to ensure more uniform distribution of elk throughout Jackson Hole.

Controlling Dispersers. One of the management alternatives that has been suggested to minimize conflicts with local livestock growers is to control wolves if they leave the park. The consequence will be to increase the mortality rate for wolves in the GYE and inhibit colonization outside the park, especially amongst packs whose territories cross into private property. This source of mortality will increase the probability of extinction for wolves, although whether this is a significant factor determining the success of the recovery effort will depend on the other management choices. So long as other sources of mortality are controlled (e.g., poaching), culling of dispersing wolves is not likely to jeopardize wolf recovery.

Poaching. Poaching within the parks could become a serious problem, and could further reduce the chances that wolf recovery would be effective. This would be much more of a threat to the continued survival of wolves in the parks than legal culling of wolves outside the parks, because legal culling would not threaten wolves in packs whose complete home range was within Yellowstone or Grand Teton National Parks.

\section{RESEARCH NEEDS}

One of the outcomes of modeling is to learn weaknesses in our empirical understanding of systems. To understand the role of wolves in shaping the dynamics of ungulate populations in Yellowstone National Park, the obvious research need is to restore wolves to the park. But to better anticipate the consequences of wolf recovery, there are clearly some data needs.

Elk and bison in Yellowstone have been monitored closely, and although our understanding of the population dynamics of these 2 species is still rudimentary, we at least have a basis for simple models. However, our understanding of moose and mule deer in the GYE is fragmentary. Our simulation results suggested, that under certain conditions, both of these species might suffer substantial local losses from wolf predation, and therefore, there is a need to learn more about the habitats, distribution, and abundance of these ungulates.

Mule deer are of concern because in winter they concentrate on private lands north of Yellowstone National Park. Also, the species is a preferred prey by wolves and populations wintering in the park may be substantially reduced by wolves. Mule deer may be critical prey for wolves during summer along the 
North Fork of the Shoshone River where a substantial fraction of the elk herd migrates seasonally (Rudd et al. 1983). Additional baseline data on mule deer distribution and movements is necessary' to be able to anticipate the probable consequences of wolf recovery.

Moose numbers in the GYE are not well known. Because moose frequent riparian areas near the road system in Yellowstone and Grand Teton National Parks, nonconsumptive use (viewing, photography) of moose in the GYE is important. Moose are important prey for wolves in other areas (Mech 1970, Ballard et al. 1986, Van Ballenberghe 1987), but they are more difficult to kill than elk or deer (Carbyn 1983) and therefore are less preferred. Nevertheless, there is particular concern about the possible consequences that wolves may have on moose numbers because of the high hunter mortality on moose outside the park, especially in Montana (Singer 1991). Yet, it is appropriate to note that moose colonized the Northern Range during the late 19th century when wolves were present (M. Meagher, pers. commun., National Park Service, Yellowstone National Park). Better information on moose numbers and ecology in the Yellowstone area is needed before we can reliably project the likely consequences of wolf recovery.

Fundamental to understanding the ecology of the large mammal ranges in the GYE is a better assessment of plant-herbivore interactions. In particular, the role that ungulates play in plant succession and community structure must be understood in response to concerns that certain ranges may be overgrazed (Beetle 1979, Chase 1986, Chadde and Kay 1991). Understanding the dynamics of the plant-herbivore system will require dissection of the foraging functional response for ungulates (see e.g., Spalinger et al. 1988), especially for elk.

Should wolf recovery take place, it will be of utmost importance to implement a vigorous program of monitoring to verify predictions of this and other models (e.g., Boyce 1990, Garton et al. 1990). And among the more important things to study during wolf recovery are the mechanisms shaping the functional response of wolves to prey abundance and availability in a multi-species system (Allen 1989, Caro 1989). Many of our predictions regarding population behavior and the effect of wolves on ungulate numbers are based upon commonly held assumptions about functional responses. These assumptions need empirical verification.

\section{- CONCLUSIONS}

We think the most appropriate way to conclude is with a few caveats. We cannot know the exact sequence of events that will occur subsequent to wolf recovery. This was the reason for our constructing a stochastic model. With the unpredictable climate in Yellowstone National Park, there are certain to be large confidence intervals surrounding any projections for animal populations in the park.

Computer simulations indicate that wolf recovery will result in a reduction in ungulate numbers. But this does not imply that management problems associated with elk and bison populations in the park will disappear. For example, the number of bison on the Northern Range will certainly not be reduced so low that seasonal movements north of the park (Meagher 1989a, 1989b) will be curtailed. Also, we will continue to observe substantial die-offs of ungulates during severe winters, although we expect that the magnitude of these should be less with wolves.

The perception that Yellowstone's Northern Range is "overgrazed" may change subsequent to wolf recovery, because "overgrazing" is often attributed to the absence of wolves, presumably a keystone predator. Ungulates will continue to concentrate on the same ranges, since these are areas of lower snow accumulation where forage is more readily available. Yet, it seems likely that these areas have been heavily grazed by ungulates since the Pleistocene, and recent palynological (pollen analysis) evidence suggests that no major trends in vegetation composition on the Northern Range during the last 11,000 years can be attributed to ungulate grazing (Whitlock et al. 1991).

We have not attempted to model livestock conflicts resulting from wolf recovery. However, after wolves have become established, we might expect approximately 15-25 wolves dispersing from Yellowstone National Park each year. We can be reasonably certain that some of these dispersing wolves will get themselves into trouble from time to time. Conflicts are likely to be most severe following initial release because translocated wolves 
are likely to disperse (Fritts et al. 1984), although strategies for release may reduce such problems (Fritts 1990). It is probable that some wolves will kill livestock and control of problem animals will be necessary (Fritts 1990).

Wolves will compete for game with hunters, and there will be differences of opinion as to whether wolves or hunters should be given priority. Hunters have very mixed opinions on whether wolf recovery is good or bad. When the senior author was organizing the conference entitled "Examining the Greater Yellowstone Ecosystem" in spring 1989, he spoke with several members of the Wyoming Guides and Outfitters Association. We were surprised to learn that the association has no official policy on wolf recovery because there is so much dissention amongst their members. Some members reflect Zumbo's (1987) view that hunting opportunities may decline as a consequence of competition between hunters and wolves. However, others see benefits from wolf recovery. One guide believed that his business depended upon providing clients with high-quality wilderness experiences in the Teton Wilderness. And what could be a higher quality wilderness experience than to hear wolves howling on the evening before embarking on a remote-country elk hunt?

We cannot know the consequences of wolf recovery until it actually takes place. Yet, we believe that our understanding of ungulate population biology and wolf predation is adequate to predict reasonable bounds for the expected population responses. We hope that the results of this model will assist resource managers in making policy related to wolf recovery.

\section{- LITERATURE CITED}

Allen, J. A. 1989. Searching for search image. Trends Ecol. Evol. 4:361.

Ballard, W. B., S. M. Miller, and J. S. Whitman. 1986. Modeling a south-central Alaskan moose population. Alces 22:201-243.

J. S. Whitman, and C. L. Gardner. 1987. Ecology of an exploited wolf population in south-central Alaska. Wildl. Monogr. 98:1-54.

Bath, A. J. 1991. What does the public think of wolf restoration in Yellowstone National Park? Pages 367-376 In: R. B. Keiter and M. S. Boyce, eds. The Greater Yellowstone Ecosystem: Redefining America's wilderness heritage. Yale Univ. Press, New Haven, Conn.

Beetle, A. A. 1979. Jackson Hole elk herd: A summary after 25 years of study. Pages 259-262 In: M. S. Boyce and L. D. Hayden-Wing, eds. North American elk: Ecology, behavior and management. Univ. Wyoming, Laramie. 294pp.

Bergerud; A. T., W. Wyeet, and B. Snider. 1983. The role of wolf predation in limiting a moose population. J. Wildl. Manage. 47:977-988.

Boyce, M. S. 1977. Population growth with stochastic fluctuations in the life table. Theor. Popul. Biol. 12:366-373.

. 1989. The Jackson elk herd: Intensive wildlife management in North America. Cambridge Univ. Press, Cambridge, U.K. 306pp.

1990. Wolf recovery for Yellowstone National Park: A simulation model. Pages 3.3-3.58 in National Park Service, ed. Wolves for Yellowstone? A report to the United States Congress, Volume II. Research and Analysis. Yellowstone National Park, Mammoth, Wyoming.

. and D. J. Daley. 1980. Population tracking of fluctuating environments and natural selection for tracking ability. Am. Nat. 115:480-491.

and J. Gaillard. 1991. Wolves in Yellowstone, Jackson Hole, and the North Fork. Final Report to Yellowstone National Park, Mammoth, WY.

. and E. H. Merrill. 1991. Effects of the 1988 fires on ungulates in Yellowstone National Park. Proc. Tall Timbers Fire Ecol. Conf. 17:121-132.

Carbyn, L. N. 1974. Wolf predation and behavioral interactions with elk and other ungulates in an area of high prey density. Ph.D. Dissertation, Univ. Toronto, Ontario, Canada. 233pp. 
1983. Wolf predation on elk in Riding Mountain National Park, Manitoba. J. Wildl. Manage. 47:963-976.

P. Paquet, and D. Meleshko. 1987. Long-term ecological studies of wolves, coyotes, and ungulates in Riding Mountain National Park. Canadian Wildlife Service, Edmonton, Alberta (mimeo).

Caro, T. M. 1989. Missing links in predator and antipredator behaviour. Trends Ecol. Evol. 4:333-334.

Caughley, G., and J. Lawton. 1981. Plant-herbivore systems. Pages 132-166 In: R. M. May, ed. Theoretical ecology. Blackwell Sci. Publ., Oxford, U.K.

Chadde, S., and C. Kay. 1991. Distribution and abundance of tall willow communities on Yellowstone's Northern range. In: R. B. Keiter and M. S. Boyce, eds. The Greater Yellowstone Ecosystem: Redefining America's wilderness heritage. Yale Univ. Press, New Haven, Conn.

Chase, A. 1986. Playing God in Yellowstone. Atlantic Monthly Press, Boston. 446pp.

Despain, D., D. Houston, M. Meagher, and P. Schullery. 1986. Wildlife in transition: Man and nature on Yellowstone's Northern Range. Roberts Rinehart, Inc., Boulder, Colo. 142pp.

Dunlap, T. R. 1988. Saving America's wildlife. Princeton University Press, Princeton, New Jersey. 222pp.

Fritts, S. H. 1990. In: National Park Service, ed. Wolves for Yellowstone? A report to the United States Congress, Volume II. Research and Analysis. Yellowstone National Park, Mammoth, Wyoming.

Fritts, S. H., W. J. Paul, and L. D. Mech. 1984. Movements of translocated wolves in Minnesota. J. Wildl. Manage. 48:709-721.

Fuller, T. K. 1989. Population dynamics of wolves in north-central Minnesota. Wildl. Monogr. No. 105. $41 \mathrm{pp}$.
Garton, E. O., R. L. Crabtree, B. B. Ackerman, and G. Wright. 1990. The potential impact of a reintroduced wolf population on the northern Yellowstone elk herd. Pages 3-61 to 3-91 In: Wolves for Yellowstone? A report to the United States Congress, Volume 2, Research and Analysis. National Park Service Yellowstone National Park, Mammoth, Wyoming.

Gasaway, W. C., R. O. Stephenson, J. L. Davis, P. E. K. Shepard, and O. E. Burris. 1983. Interrelationships of wolves, prey, and man in interior Alaska. Wildl. Monogr. No. 84. 50pp.

Gunson, J. 1986. Wolves and elk in Alberta's Brazeau country. Bugle 4:29-33.

- 1982. The Northern Yellowstone elk: ecology and management. Macmillan, New York. 474pp.

Inoue, M., and H. Kamifukumoto. 1984. Scenarios leading to chaos in a forced Lotka-Volterra model. Progr. Theor. Phys. 71:930-937.

Keith, L. B. 1983. Population dynamics of wolves. Pages 66-77 In: L. N. Carbyn, ed. Wolves in Canada and Alaska: their status, biology, and management. Can. Wildl. Serv. Rep. Ser. No. 45. 133pp.

May, R. M. 1989. Detecting density dependence in imaginary worlds. Nature 338:16-17.

McNaught, D. A. 1987. Wolves in Yellowstone?--Park visitors respond. Wildl. Soc. Bull. 15:518-521.

Meagher, M. M. 1971. Winter weather as a population regulating influence on free-ranging bison in Yellowstone National Park. American Association for the Advancement of Science Symposium on Research in National Parks, Philadelphia, PA. (mimeo).

- 1989a. Evaluation of boundary control for bison of Yellowstone National Park. Wildl. Soc. Bull. 17:15-19.

- 1989b. Range expansion by bison of Yellowstone National Park. J. Mammal. 70:670-675. 
- 1970. The wolf: The ecology and behavior of an endangered species. Natural History Press, New York. 385pp.

. and P. D. Karns. 1977. Role of the wolf in a deer decline in the Superior National Forest. U.S. Department of Agriculture, Forest Service, Res. Pap. NC-148, N. Cent. Forest Exp. Sta., St. Paul, MN. 23pp.

Merrill, E. H., and M. S. Boyce. 1991. Summer range and elk population dynamics in Yellowstone National Park. Pages 263-273 In: R. B. Keiter and M. S. Boyce, eds. The Greater Yellowstone Ecosystem: Redefining America's wilderness heritage. Yale Univ. Press, New Haven, Conn.

. M. S. Boyce, R. Marrs, and M. Brodahl. 1988. Relationships among climatic variation, grassland phytomass and ungulate population characteristics on the northern range of Yellowstone National Park. Unpublished Final Report for the Univ. Wyo.-Nat. Park Service Res. Center, Laramie, Wyoming. 64pp.

Murie, O. J. 1951. Do you want hunting in our National Parks? Nat. Hist. 60:464-467.

Packard, J. M., and L. D. Mech. 1980. Population regulation in wolves. Pages 135-150 In: A. G. Klein and $M$. Cohen, eds. Biosocial mechanisms of population regulation. Yale University Press, New Haven, Conn.

. and L. D. Mech. 1983. Population regulation in wolves. Pages 151-174 In: F. L. Bunnell, D. S. Eastman, and J. M. Peek, eds. Symposium on natural regulation of wildlife populations. For., Wildl. and Range Exp. Sta., Univ. Idaho, Moscow.

Rudd, W. J., A. L. Ward, and L. L. Irwin. 1983. Do split hunting seasons influence elk migrations from Yellowstone National Park? Wildl. Soc. Bull. 11:328-331.

- 1991. The ungulate prey base for wolves in Yellowstone National Park. Pages 323-348 In: R. B. Keiter and M. S. Boyce, eds. The
Greater Yellowstone Ecosystem: Redefining America's wilderness heritage. Yale Univ. Press, New Haven, Conn.

. and P. Schullery. 1989. Yellowstone wildlife: Populations in process. West. Wildl. 15(2):18-22.

. W. Schreier, J. Oppenheim, and E. O. Garton. 1989. Drought, fires, and large mammals. BioScience 39:716-722.

Spalinger, D. E., T. A. Hanley, and C. T. Robbins. 1988. Analysis of the functional response in foraging in the Sitka black-tailed deer. Ecology 69:1166-1175.

Sugihara, G., and R. M. May. 1990. Nonlinear forecasting: An operational way to distinguish chaos from measurement error. Nature 344:734-741.

U. S. Fish and Wildlife Service. 1987. Northern Rocky Mountain wolf recovery plan. U. S. Fish and Wildlife Service, Denver, Colo. 119pp.

Van Ballenberghe, V. 1987. Effects of predation on moose numbers: A review of recent North American studies. Swedish Wildl. Res., Suppl. 1, 1987:431-460.

Weaver, J. L. 1978. The wolves of Yellowstone. US Nat. Park Serv., Nat. Res. Rep. No. 14. 38pp.

Whitlock, C. W. B., S. C. Fritz, and D. R. Engstrom. 1991. A prehistoric perspective on the Northern Range. Pages 289-305 In: R. B. Keiter and M. S. Boyce, eds. The Greater Yellowstone Ecosystem: Redefining America's wilderness heritage. Yale University Press, New Haven, Conn.

Wood, P. 1984. The elk hunt goes on at Grand Teton. Nat. Parks 58:29-31.

Zumbo, J. 1987. Should we cry wolf? Outdoor Life, Dec. 1987:50-53. 